JOANNA MACHLAŃSKA

Uniwersytet Jagielloński

\title{
PRZESTĘPSTWO CIĄGŁE WE WSPÓŁCZESNYM ROSYJSKIM PRAWIE KARNYM
}

Nauka polskiego prawa karnego rzadko sięga po dorobek rosyjski, a zdecydowana większość przedstawicieli piśmiennictwa skupia się na niemieckich doświadczeniach. Można by nawet zaryzykować stwierdzenie, że rosyjskie prawo karne jest przez nas ignorowane, mimo że na polskich ziemiach zaboru rosyjskiego obowiązywały rosyjskie ustawy karne, m. in.: Kodeks kar głównych i poprawczych, Kodeks karny z 1903 r. - tzw. Kodeks Tagancewa (który obowiązywał także już w II Rzeczypospolitej do czasu wejścia w życie Kodeksu Makarewicza z 1932 r.), a następnie w okresie komunizmu to Związek Radziecki w największym stopniu wpływał na polskie ustawodawstwo.

Można spostrzec, że również w odniesieniu do problematyki ciągłości popełnienia przestępstwa Polska i Rosja miały ze sobą wiele wspólnego, w szczególności biorąc pod uwagę okres po Rewolucji z 1917 r. na ziemiach rosyjskich oraz okres po 1944 r. w Polsce. Za czasów komunizmu w obu państwach przestępstwo ciągłe było przedmiotem dużego zainteresowania ze względu na wzmożoną ochronę mienia społecznego i państwowego, a zamachy na te dobra były ścigane w sposób szczególnie surowy, o czym świadczyło wydawanie wielu dekretów oraz ustaw mających przeciwdziałać tego typu zamachom. Wówczas zarówno w Polskiej Rzeczpospolitej Ludowej, jak i Rosyjskiej Federacyjnej Socjalistycznej Republice Radzieckiej konstrukcja ta była stosowana dowolnie przez sądy i miała ona charakter pozaustawowy. 
Znamienny dla współczesnego rosyjskiego prawa karnego jest fakt, że do tej pory postanowienie Plenum Sądu Najwyższego ZSRR z 4 marca 1929 r., które definiuje przestępstwo ciągłe jako „s k ła d a jące się z szeregu przestępnych, tożsamych czynności ukierunkowanych na ogólny cel, stanowiących przestępstwo jednostkowe" stanowi wstęp do rozważań o tej instytucji ${ }^{1}$, co z polskiego punktu widzenia stanowi fenomen, gdyż żadnemu z judykatów wydanych w okresie PRL nie przypisywano tak ogromnego znaczenia. Na przedpolu rozważań należy także podkreślić, że również w obecnie obowiązującym rosyjskim Kodeksie karnym z 1996 r. (dalej: ros.k.k.) nie uregulowano konstrukcji przestępstwa ciągłego, co tłumaczone jest tym, że po dzisiaj nie wypracowano wspólnego stanowiska odnośnie do jego przesłanek czy kształtu.

Rosyjska ustawa karna nie zawiera zakazu multiplikacji przestępstw przez multiplikację ocen, w związku z czym trudno określić, co jest podstawą prawnokarnego wartościowania w przypadku konstrukcji przestępstwa ciągłego. Do tej pory nie zostało wydane żadne opracowanie dotyczące tej problematyki. Nie ulega wątpliwości, że przestępstwo ciągłe jest jednym z rodzajów przestępstwa jednostkowego złożonego ${ }^{2}$ i że stanowi jedno przestępstwo. Jednakże trudno znaleźć odpowiedź na pytanie, co składa się na to jedno przestępstwo. Wydaje się, że nikt do tej pory nie zaprezentował stanowiska, że na przestępstwo ciągłe składają się dwa lub więcej zachowań. Większość autorów stwierdza, że na przestępstwo ciągłe składa się szereg działań (zaniechań) lub czynności ${ }^{3}$, co także nie jest pomocne przy rozważaniu podstawy wartościowania.

1 Ze szczegółowymi rozważaniami na temat konstrukcji przestępstwa ciągłego do 1929 r. w rosyjskim prawie karnym oraz komentarzem do postanowienia z 4 marca 1929 r. można zapoznać się w opracowaniu: J. Machlańska, Przestępstwo ciągłe w rosyjskim prawie karnym do 1929 r., «PiP» 70.9/2015, s. 110-112.

2 Na temat pojęcia i podziału przestępstwa jednostkowego por. EADEM, Wymiar kary za zbieg przestępstw i zbieg wyroków w rosyjskim prawie karnym, "CPKiNP» 3/2016, s. 153-156.

3 Warto zauważyć, że także w art. 17 ust. 2 ros. k.k. dot. zbiegu przepisów jest mowa o działaniu (zaniechaniu), a nie o jednym czynie - „Zbieg przestępstw stanowi jedno działanie (zaniechanie) wypełniające znamiona przestępstw przewidzianych przez dwa lub więcej artykułów niniejszego Kodeksu" (Совокупностью преступлений 
Zarazem ci sami autorzy zazwyczaj wspominają, że na przestępstwo ciągłe składa się kilka czynów, lecz - ponownie - odnoszą się do tego stwierdzenia bez żadnego uzasadnienia, skupiając się na innych przesłankach tej instytucji.

Wydaje się, że prawdopodobnie tylko jeden przedstawiciel doktryny zaryzykował stwierdzenie, że przestępstwo ciągłe „składa się z szeregu jednorodnych, objętych jednością winy czynności, spośród których żadna czynność nie ma charakteru samodzielnego przestępstwa, a stanowi etap, kontynuację jednego i tego samego przestępnego czynu"4. Według W. P. Małkowa czynności te stanowią jeden czyn, czyli w tym zakresie przestępstwo ciągłe jest podobne do polskiej konstrukcji czynu ciągłego. Z drugiej strony jednak z trudnością można wywnioskować, czy takie spojrzenie było świadome, skoro autor w bardziej rozległy sposób nie wypowiedział się na ten temat. Z tak krótkiego stwierdzenia niestety trudno wyciągnąć dalekosiężne konsekwencje, w szczególności biorąc pod uwagę fakt, że w swoich późniejszych opracowaniach W. P. Małkow „odstąpił” od swojego poglądu, dochodząc do wniosku, że na przestępstwo ciągłe mogą składać się także czyny (a nie czyn), które nie stanowią przestępstwa.

Następnym z problemów, jakie rodzi przestępstwo ciągłe w nauce współczesnego prawa karnego, to zagadnienie związane z tym, czy zachowania wchodzące w jego skład mają być tożsame (realizować znamiona tego samego typu czynu zabronionego, wszystkie epizody powinny być podobne do siebie zarówno formą, jak i sposobem ich popełnienia ${ }^{5}$ ), czy jednorodne (realizujące znamiona różnych typów czynów zabronionych, ale stanowiących zamach na to samo dobro

признается и одно действие (бездействие), содержащее признаки преступлений, предусмотренных двумя или более статьями настоящего Кодекса).

„Слагаются из ряда однородных, объединенных единством вины действий, каждое из которых не носит характера самостоятельного преступления, а является этапом, приемом, продолжением одного и того же преступного деяния" В.П. МАлков, Повторность преступлений [Powtórność przestępstw], Казань 1970, S. 86 .

М. СтАНовСКиЙ, Понятие продолжаемого преступления [Pojęcie przestępstwa ciagłego], «Российская юстиция» 11/1995, s. 36. 
prawne, a typy czynów zabronionych są ujęte w Kodeksie w tym samym rozdziale). Większość autorów stoi na pierwszym stanowisku ${ }^{6}$, jednakże można znaleźć także przedstawicieli piśmiennictwa, którzy są zwolennikami drugiego poglądu ${ }^{7}$ Opowiadając się za tym, że na przestępstwo ciągłe mogą składać się jedynie zachowania tożsame, należy zaznaczyć, że w przeciwnym przypadku nie zostało określone, do jakiego stopnia mają być jednorodne poszczególne czynności sprawcze, gdyż co prawda np. kradzież, rozbój, przywłaszczenie są to jednorodne typy czynów zabronionych, to jednak w przypadku podjęcia się czynów realizujących znamiona tych typów czynów zabronionych trudno mówić o ogólnym zamiarze i jednym celu ${ }^{8}$.

Kolejnym zagadnieniem, z którym zmaga się współczesne prawo karne, jest kwestia tego, czy poszczególne zachowania wchodzące w skład przestępstwa ciągłego mają samodzielnie realizować znamiona typu czynu zabronionego. W literaturze zostały przedstawione trzy poglądy:

1) każdy z aktów samodzielnie realizuje znamiona typu czynu zabronionego';

6 Por. również orzecznictwo: postanowienie Plenum Sądu Najwyższego Federacji Rosyjskiej z 15 czerwca 2004 r., „O orzecznictwie w sprawach o przestępstwach przewidzianych art. 131 i 132 Kodeksu karnego Federacji Rosyjskiej” (постановление Пленума Верховного Суда РФ от 15 июня 2004 года «О судебной практике по делам о преступлениях, предусмотренных статьями 131 и 132 Уголовного кодекса Российской Федерации»); postanowienie Plenum Sądu Najwyższego FR z 27 grudnia 2007 nr 51 „O orzecznictwie w sprawach o oszustwo, przywłaszczenie i defraudację” (постановление Пленума Верховного Суда РФ от 27 декабря 2007 г. «О судебной практике по делам мошенничестве, присвоении и растрате»).

7 Т.Э. КАРАЕВ, Повторность преступлений [Powtórność przestępstw], Москва 1983, s. 10; Н.Ф. КузНЕцОвА, Квалификация сложных составов преступлений [Кжаlifikacja złożonych typów czynów zabronionych], «Уголовное право» 1/2000, s. 32).

${ }_{8}$ Rozważania dotyczące subiektywnych przesłanek przestępstwa ciągłego będą zaprezentowane w dalszej części niniejszego opracowania.

9 H.С. ТАГАНЦЕв, Русское уголовное право. Лекиии. Часть общзя, II, [Rosyjskie prawo karne. Wykłady. Część ogólna, II,], Москва 1994, s. 259; А.А. Пионтковский, Уголовное право РСФСР. Общзая часть [Prawo karne RFSSR. Część ogólna], Москва 1925, s. 633. 
2) każdy z aktów samodzielnie nie realizuje znamion typu czynu zabronionego ${ }^{10}$;

3) akty mogą być zarówno przestępstwami, jak i wykroczeniami ${ }^{11}$.

Większość przedstawicieli piśmiennictwa opowiada się za trzecim poglądem, traktując takie rozwiązanie za najbardziej rozsądne, gdyż w przeciwnym razie mogłoby dochodzić do nieuzasadnionego różnicowania odpowiedzialności karnej sprawcy w zależności od tego, na przykład, w ilu etapach i w jakiej wielkości kradł cudze rzeczy. Biorąc pod uwagę fakt, że w rosyjskim prawie karnym kradzież stanowi przestępstwo, jeśli wartość skradzionego mienia przekracza 1.000 rubli $^{12}$, to często nawet małe różnice w kwotach decydowałyby o tym, czy sprawca będzie odpowiadał za przestępstwo ciągłe kradzieży czy zbieg drobnych kradzieży (administracyjnych wykroczeń). W takim przypadku pociągnięcie do odpowiedzialności w trybie administracyjnym zostało uznane za niesprawiedliwe, wręcz nazwano odpowiedzialność za związane ze sobą czyny ukierunkowane na osiągnięcie skonkretyzowanego rezultatu, objęte ogólnym celem i wspólnym zamiarem, gdy wartość skradzionych rzeczy nie przekracza 1.000 rubli „prawniczym potworem"13. W związku z powyższym przedstawiono pogląd, by do teorii prawa karnego wprowadzić pojęcie „częściowo kryminalizowanego przestępstwa ciągłego". Wówczas w skład przestępstwa jednostkowego

10 В.П. МАлков, Совокупность преступлений [Zbieg przestępstw], Казань 1974, s. 116.

11 Т.Э. КАРАЕВ, ор. cit., s. 81; М. СТАНОВСКИЙ, op. cit.; Н.И ПрЯХИНА, В.Ф. ЩЕПЕЛЬКов, Об отграничении продолжаемого преступления от совокупности преступлений [O rozgraniczeniu przestępstwa ciagłego od zbiegu przestępstw], «Криминалистъ» 1/2011, s. 8 .

12 Poniżej tej wartości kradzież stanowi administracyjne wykroczenie, por. art. 7.27 Kodeksu o administracyjnych wykroczeniach oraz federalną ustawę „O wniesieniu zmian w art. 3.5 i 7.27 Kodeksu Federacji Rosyjskiej o administracyjnych wykroczeniach” z 16 maja 2008 r., nr 74-F3, «Rosyjska gazeta» z 20 maja 2008 r., nr 106 (Федеральный закон «О внесении изменений в статье 3.5 и 7.27 Кодекса Российской Федерации об административных правнонарушениях» от 16 мая 2008 г., № 74-Ф3, «Российская газета» 2008, № 106, 20 мая).

13 А.П. КОзЛОв, А.П. СЕВАСТьянов, Единичные и множественные преступления [Jednostkowe przestępstwa i wielość przestępstw], Санкт-Петербург 2011, s. 62-63. 
mogłyby wchodzić administracyjne wykroczenia, co m. in. umożliwiłoby zmniejszenie sankcji karnej ${ }^{14}$.

Jednocześnie większość autorów sprzeciwia się temu, by w skład przestępstwa ciągłego mogły wchodzić tylko administracyjne wykroczenia, stwierdzając, że taki pomysł jawnie narusza zasadę nullum crimen sine lege.

Po dzisiaj nie udało się wypracować jednolitego stanowiska w sprawie tego, jak długo mają trwać przerwy pomiędzy poszczególnymi epizodami. Większość autorów nie konkretyzuje długości tego okresu, jednocześnie zaznaczając, że dłuższe przerwy (np. trwające dłużej niż 2 miesiące) nie mogą świadczyć o wspólnym zamiarze dokonania poszczególnych zachowań i w takiej sytuacji sprawca powinien ponieść odpowiedzialność karną za zbieg przestępstw ${ }^{15}$. Zarazem wyrażono pogląd, że niezależnie od długości przerwy (która mogłaby nawet trwać latami) możliwe jest przypisanie przestępstwa ciągłego, bowiem przerwa nie zmienia charakteru przestępstwa, o ile przez ten czas nie doszło do przedawnienia karalności bądź ścigania ${ }^{16}$.

Liczne dyskusje wywołała także przesłanka „tożsamości źródła” w odniesieniu do przestępstw przeciwko mieniu. Jakkolwiek sformułowanie to istnieje od lat w teorii prawa karnego, gdy jest mowa o przestępstwie ciągłym, to nadal nie ma jego definicji i nie wiadomo, co należy rozumieć pod tym pojęciem. Wydaje się, że na gruncie obecnie obowiązującego Kodeksu karnego odchodzi się od tego wymogu, często obrazując absurdalność tego pomysłu, zaznaczając, że jeśli opowiedzieć się za istnieniem tej przesłanki, to wówczas rodzą się problemy z chociażby prostą sytuacją polegającą na kradzieżą płaszczy z jednej szatni. Z jednej strony, szatnia stanowi owo „jedno źródło”, gdyż jest zachowana tożsamość miejscowa, z drugiej jednak strony źródła są różne, bo jest

14 Ibidem, s. 63-64.

15 В. КвАшис, Ю. Крутов, Некоторые вопросы квалификации продолжаемых nреступлений [Niektóre zagadnienia kwalifikacji przestępstw ciagłych], "Советская юстиция» 12/1966, s. 16 і n.; Н.Г. Иванов, Уголовное право России. Общзая и особенная части: Учебник для вузов [Prawo karne Rosji. Część ogólna i szczególna: Podręcznik dla uczelni], Москва 2003, s. 312.

16 А.П. КОзЛОв, А.П. СЕвАСТьянов. op. cit., s. 57. 
kilku pokrzywdzonych - nie wiadomo zatem jak interpretować to znamię - czy jako wymóg tożsamości miejscowej czy jako wymóg tożsamości pokrzywdzonego ${ }^{17}$. Równocześnie krytykując wymóg występowania „wspólnego źródła” przy przestępstwach przeciwko mieniu, zauważa się, że przestępstwo ciągłe stanowi instytucję części ogólnej prawa karnego, nieuzasadnione jest więc stwarzanie dodatkowych wymogów tylko w stosunku do konkretnej kategorii typów czynów zabronionych ${ }^{18}$.

Odnosząc się do subiektywnej przesłanki przestępstwa ciągłego, należy zwrócić uwagę, że także w literaturze przedstawiano różne koncepcje dotykające tej problematyki, podkreślając, że funkcjonalna więź pomiędzy poszczególnymi przestępnymi aktami powinna być potwierdzona subiektywną więzią, a również że właśnie ta przesłanka w przeciwieństwie od pozostałych, tj. kilku czynności, ich tożsamości, itd., które nie mogą być bardziej skonkretyzowane - może i powinna być bardziej skonkretyzowana i dodatkowo występować tylko przy przestępstwie ciągłym, być typową dla tej instytucji ${ }^{19}$.

W teorii rosyjskiego prawa karnego podjęto już próby uszczegółowienia tego znamienia, stwierdzając, że „Przestępstwo ciągłe składa się $\mathrm{z}$ oddzielnych jednorodnych aktów z jednym przestępnym zamierzeniem na osiągnięcie wcześniej postawionego sobie celu" [podkr. - aut.], jednocześnie dodając, że powinien występować jeden zamiar ukierunkowany na zawładnięcie nad mieniem „w mniej lub bardziej określonym rozmiarze" ${ }^{20}$. Z niniejszego wynika, że cel nie tylko musi istnieć przed podjęciem pierwszej czynności, ale także winien być określony (jakkolwiek sformułowania „mniej lub bardziej określony” nie można potraktować za najbardziej trafne).

Bardziej skonkretyzowany stosunek co do tej problematyki prezentowali inni przedstawiciele piśmiennictwa, m. in. Z.A. Wyszynskaja zaznaczała, że ciągła kradzież występuje w przypadku, „kiedy ustanowiono, że

17 Н.И. ПряхинА, В.Ф. Щепельков, op. cit.

18 А.П. Козлов, А.П. Севастьянов, op. cit.

19 Ibidem, s. 53-54.

20 В. ВлАдимиРОв, Г. КРИволАПов, Соотношение продолжаемых и повотрных преступлений [Współzależność ciagłych i powtórnych przestępstw], «Советская юстиция»19/1974, s. 10. 
zamiar winnego niejednokrotnie dokonującego zaboru z jednego źródła był ukierunkowany na przestępne zawładnięcie jakimkolwiek wcześniej przez siebie określonym majątkiem lub jego częścią, ale było ono dokonywane przez sprawcę na raty" ${ }^{21}$. Natomiast A. Wasecow wspomniał, że wszystkie czyny „mają określony cel”22. Podobnie uważała W. I. Płochowa, twierdząc, że wspólny zamiar na zabór majątku w konkretnie określonym rozmiarze stanowi nieodłączne znamię przestępstwa ciągłego $^{23}$. Ta myśl podlegała dalszemu rozwojowi - „Najważniejsze znaczenie dla przyjęcia ciągłego zaboru ma występowanie u sprawcy wspólnego zamiaru ukierunkowanego na zawładnięcie socjalistycznym mieniem w określonym rozmiarze, objętości, wartości” ${ }^{24}$; „Niejednokrotne tożsame czyny przy przestępstwach ciągłych powinny być ukierunkowane na to samo dobro prawne, skonkretyzowane w przedmiocie czynności wykonawczej" ${ }^{25}$. Można więc stwierdzić, że niektórzy autorzy wspominali o skonkretyzowanym celu, a inni o skonkretyzowanym dobrze prawnym i przedmiocie zamachu. Jednocześnie zwraca się uwagę na to, że w przypadku nieukończonego przestępstwa ciągłego nie dochodzi do naruszenia dobra prawnego, trudno więc mówić o z góry określonym dobrze prawnym, które ma podlegać zniszczeniu, jeśli do tego nie

21 3.А. ВышинскАя, Судебная практика по делам о хищениях имущества в колхозах и совхозах, Научный комментарий по гражданским и уголовным делам [Orzecznictwo w sprawach o zabór majątku w kołchozach i sowchozach, [w:] Naukowy komentarz do orzecznictwa w sprawach cywilnych i karnych], Москва 1962, s. 181.

22 А. ВАСЕцов, Квалификация повторных преступных посягательств на соицалистическую и личную собственность [Kwalifikacja powtórnych przestępnych zamachów na socjalistyczną i prywatna własność], «Советская юстиция» 3/1983, s. 10.

23 В.И. ПлоховА, О продолжаемых хищениях, совершаемых в борме присвоения, растраты либо злоупотребления служебным положением, [w:] Эфбективность уголовного права на современном этапе [O ciagłych zaborach dokonanych $w$ formie przywłaszczenia, defraudacji albo nadużycia urzędowych obowiązków, [w:] Efektywność prawa karnego na współczesnym etapie], отв. ред. М.И. КовАлЕв, Свердлоск 1977, s. 47.

24 К. КРемнев, М. Миненок, Квалификация продолжаемых и повторных хищеений [Kwalifikacja ciagłych i powtórnych przestepstw], «Советская юстиция» 10/1990, s. 9.

25 М. СТАНОВСКИЙ, op. cit. 
dochodzi, dlatego słusznie twierdzi się, że to skonkretyzowany ogólny cel stanowi znamię przestępstwa ciągłego ${ }^{26}$.

Z tematyką subiektywnych przesłanek przestępstwa ciągłego nierozerwalnie wiążą się kwestie szczegółowe związane ze stroną podmiotową zachowań nań składających się ${ }^{27}$, tj. czy można ich dokonywać nie tylko

26 А.П. КОзЛОв, А.П. СЕВАСТьянов, op. cit., s. 56.

27 Zgodnie $\mathrm{z}$ obowiązującym rosyjskim Kodeksem karnym za przestępstwo popełnione umyślnie uznaje się czyn popełniony z zamiarem bezpośrednim lub pośrednim (art. 25 ust. 1). Przestępstwo jest dokonane z zamiarem bezpośrednim, jeśli sprawca uświadamiał sobie społeczną szkodliwość swoich działań (zaniechań), przewidywał możliwość lub nieuchronność wystąpienia społecznie szkodliwych skutków i chciał ich nastąpienia (art. 25 ust. 2). Przestępstwo z zamiarem pośrednim jest popełnione wówczas, kiedy sprawca uświadamiał sobie społeczną szkodliwość swoich działań (zaniechań), przewidywał możliwość wystąpienia społecznie szkodliwych skutków, nie chciał, ale świadomie dopuszczał możliwość wystąpienia tych skutków albo traktował je z obojętnością (art. 25 ust. 3). Natomiast przestępstwa nieumyślne są dokonane lekkomyślnie lub z niedbalstwa (art. 26 ust. 1). Przestępstwo jest popełnione lekkomyślnie, jeśli sprawca przewidywał możliwość wystąpienia społecznie szkodliwych skutków swoich działań (zaniechań), ale bez dostatecznych ku temu podstaw z pewnością siebie liczył na odwrócenie tych skutków (art. 26 ust. 2). Przestępstwo jest uznawane za popełnione $z$ niedbalstwa, jeśli sprawca nie przewidywał możliwości wystąpienia społecznie szkodliwych skutków swoich działań (zaniechań), chociaż przy niezbędnej uwadze i przewidywalności powinien był i mógł przewidzieć te skutki (art. 26 ust. 3). Статья 25. Преступление, совершенное умышленно 1. Преступлением, совершенным умышленно, признается деяние, совершенное с прямым или косвенным умыслом. 2. Преступление признается совершенным с прямым умыслом, если тицо осознавало общественную опасность своих действий (бездействия), предвидело возможность или неизбежность наступления общественно опасных последствий и желало их наступления. 3. Преступление признается совершенным с косвенным умыслом, если лицо осознавало общественную опасность своих действий (бездействия), предвидело возможность наступления общественно опасных последствий, не желало, но сознательно допускало эти последствия либо относилось к ним безразлично. Статья 26. Преступление, совершенное по неосторожности 1. Преступлением, совершенным по неосторожности, признается деяние, совершенное по легкомыслию или небрежности. 2. Преступление признается совершенным по легкомыслию, если лицьо предвидело возможность наступления общественно опасных последствий своих действий (бездействия), но без достаточных к тому оснований самонадеянно рассчитывало на предотвращение этих последствий. 3. Преступление признается 
z zamiarem bezpośrednim, ale także pośrednim, a czy ponadto mogą to być również zachowania nieumyślne.

Zdecydowana większość autorów opowiada się za stwierdzeniem, że przestępstwo ciągłe może być popełnione umyślnie, zarówno z zamiarem bezpośrednim, jak i pośrednim ${ }^{28}$. Równocześnie część przedstawicieli piśmiennictwa wyraża pogląd, że w tym przypadku zachowania mogą charakteryzować się jedynie zamiarem bezpośrednim, traktując przesłankę jednego celu jako sytuację, w której „sprawca uświadamia sobie społeczną szkodliwość swoich czynności, rozumie nieuchronność osiągnięcia rezultatu tylko drogą etapowego dokonywania poszczególnych czynności i poprzez częściowe oddzielne rezultaty uświadamia sobie rozwój obiektywnej więzi między oddzielnymi czynami i oddzielnymi rezultatami, między oddzielnymi aktami i ogólnym rezultatem, chce osiągnięcia każdego rezultatu w oddzielności i ogólnego rezultatu”. Autorzy ci podnoszą, że za tym poglądem przemawia fakt, że dzięki temu istnieje możliwość rozgraniczenia przestępstw ciągłych i powtarzalnych $^{29}$. Jednakże zwolennicy twierdzenia, że przestępstwo ciągłe może być popełnione również z zamiarem pośrednim, krytykują taką argumentację, twierdząc, że wystarczającym dla przyjęcia odpowiedzialności karnej za przestępstwo ciągłe jest występowanie ogólnego zamiaru, a niepotrzebne jest dodawanie, że sprawca powinien działać także z ogólnym celem, gdyż bezpodstawnie przesądza to o zamiarze bezpośrednim ${ }^{30}$. Zdecydowana mniejszość autorów stanęła na stanowisku, że przestępstwo ciągłe może być popełnione także nieumyślnie,

совершенным по небрежности, если лиио не предвидело возможности наступления общественно опасных последствий своих действий (бездействия), хотя при необходимой внимательности и предусмотрительности должно было и могло предвидеть эти последствия.

28 И. КЛИвеР, Разграничение продолжаемых и повторных преступлений [Odgraniczenie ciagłych i powtórnych przestępstw], «Советская юстиция» 5/1979, s. 52; А.М. ОРАЗдУРДЫЕв, Проблемы общей части науки уголовного права [Problemy nauki o ogólnej części prawa karnego], Ашхабад 1991, s. 63; Н.Ф. КузнЕцовА, ор. cit., s. 32 .

29 А.П. КОзЛОв, А.П. СЕВАСТьяНОв, ор. cit., s. 64-67.

30 Н.И. ПРЯХИНА, В.Ф. ЩЕПЕЛЬКОВ, op. cit., s. 9. 
za przykład podając zanieczyszczenie morza z wykorzystaniem przestępczej techniki ${ }^{31}$.

Omawiając przesłankę skonkretyzowanego ogólnego celu, nie sposób nie wspomnieć o tym, do czego ma odnosić się ten cel. Sprawca wcześniej stawia sobie cel, rozumiejąc, że może go osiągnąć poprzez „sieć kilku celów", które systematycznie przybliżają go ku temu ogólnemu celowi - ogólny cel stanowi syntezę wszystkich pomniejszych celów. Jednocześnie cel ten powinien być z góry określony, biorąc pod uwagę rozmiar, objętość, ilość, masę, itd., po osiągnięciu których sprawca kończy swoją działalność.

Według niektórych autorów ogólny cel może podlegać korekcie polegającej na pomniejszeniu bądź powiększeniu zakresu np. kradzionych towarów, a sam cel powinien być „stosunkowo” określony ${ }^{32}$, jednakże wskazuje się, że jeżeli w trakcie dokonywania przestępstwa ciągłego doszło do zmiany celu, to pociąga to za sobą zmianę kwalifikacji prawnej ${ }^{33}$.

Jednocześnie z osiągnięciem zaplanowanego celu dochodzi do zakończenia przestępstwa ciągłego i zdecydowana większość przedstawicieli nauki rosyjskiego prawa karnego za koniec przestępstwa ciągłego uważa dokonanie ostatniego zachowania wchodzącego w jego skład ${ }^{34}$. Zarazem można spotkać się z poglądem, że przestępstwo ciągłe jest zakończone z chwilą podjęcia pierwszej czynności sprawczej, a cała

31 Т.Э. КАРАEB, op. cit., s. 82.

32 К. КРемНЕВ, М. МиНЕНОК, оp. cit., s. 9.

33 А.П. КозЛОв, А.П. СЕВАСТьянов, op. cit., s. 67.

34 Постатейный комментарий к Уголовному кодексу Российской Федераиии [Uzupetniony komentarz do kodeksu karnego Federacji Rosyjskiej], ред. А.И. ЧучАЕВ, Москва 2004, s. 188; И. КАмынин, Особенности определения сроков давности по длящимся и продолжаемьм преступлениям [Osobliwości stosowania okresów przedawnienia do przestępstw trwałych i ciagłych], «Законность»1/2004, s. 29; Н.Н. БАЙмАковА, Длящиеся и продолжаемые преступления: время совершения и практическое значение момента их окончания [Przestępstwa ciagłe i trwałe: czas popetnienia i praktyczne znaczenia momentu ich zakończenia], «Российское правосудие» 3/2011, s. 73. 
późniejsza działalność przestępcza zachodzi w ramach zakończonego przestępstwa i nie wpływa na kwalifikację prawną ${ }^{35}$.

Warto zauważyć, że pojęcie przestępstwa ciągłego znajduje się w Zarządzeniu Prokuratury Generalnej Federacji Rosyjskiej, Ministerstwa Spraw Wewnętrznych Federacji Rosyjskiej z 29 grudnia 2005 r. „O wspólnej ewidencji przestępstw” i jest określone jako „Przestępstwo składające się z szeregu tożsamych czynów (działań lub zaniechań) ukierunkowanych ku jednemu celowi, objętych przez sprawcę jednym zamiarem, charakteryzujących się jednością dobra prawnego, możliwych skutków przestępnych i kwalifikowanych jako jedno przestępstwo" ${ }^{36}$. $\mathrm{Na}$ ten termin powołują się pracownicy organów wymiaru sprawiedliwości przy rejestracji i ewidencjonowaniu przestępstw, jednakże nie może on stanowić prawnej podstawy dla kwalifikacji przestępstw przez sąd.

Zarazem trzeba zwrócić uwagę, że niektórzy przedstawiciele współczesnej nauki prawa karnego przedstawili swoją propozycję co do kształtu definicji przestępstwa ciągłego. Taką próbę podjął m. in. M. Stanowskij: „Przestępstwo ciągłe stanowi przestępstwo złożone z niejednokrotnych, objętych jednością winy i celów, tożsamych czynów będących oddzielnymi aktami jednej działalności sprawcy ukierunkowanej na jedno i to samo bezpośrednie dobro prawne albo przedmiot zamachu dla osiągnięcia

35 Н.Ф. Мурашов, Преступление: вопросы и ответы (по Уголовному кодексу Российской Федераици) [Przestępstwo: pytania i odpowiedzi (dot. Kodeksu karnego Federacji Rosyjskiej)], Москва 2001, s. 66-67.

36 Приказ Генеральной прокуратуры Российской Федерации, Министерства внутренних дел Российской Федерации, Министерства Российской Федерации по делам гражданской обороны, чрезвычайным ситуациям и ликвидации последствий стихийных бедствий, Министерства юстиции Российской Федерации, Федеральной службы безопасности Российской Федерации, Министерства экономического развития и торговли Российской Федерации, Федеральной службы Российской Федерации по контролю за оборотом наркотиков от 29 декабря 2005 г. nr 39/1070/1021/253/780/353/399 г. Москва „О едином учете преступлений”: „продолжаемое преступление, то есть преступление, складывающееся из ряда юридически тождественных деяний (действия или бездействия), направленных к единой цели, объединенных единым умыслом, единством объекта посягательства, возможных преступных последствий и квалифицируемых как одно преступление”. 
ogólnego rezultatu” ${ }^{37}$ oraz M.A. Fomin: „Jednostkowe przestępstwo ciągłe stanowi przestępstwo, które składa się z szeregu oddzielnych tożsamych czynności objętych jednością zamiaru i ukierunkowanych na jeden i ten sam przedmiot zamachu z celem osiągnięcia określonego celu"38.

W oparciu o powyższe rozważania można zauważyć, że po dzień dzisiejszy nie wypracowano w teorii rosyjskiego prawa karnego jednego wspólnego stanowiska co do definicji przestępstwa ciągłego. Definiując przestępstwo ciągłe, różni autorzy wymieniają odmienne znamiona, np.:

1. popełnienie kilku tożsamych lub jednorodnych czynów,

2. każdy czyn powinien wyczerpywać znamiona typu zabronionego,

3. czyny mogą stanowić zarówno przestępstwa, jak i wykroczenia,

4. to samo źródło pochodzenia skradzionych rzeczy ${ }^{39}$,

5. wspólne skutki,

6. to samo dobro prawne,

7. podobny sposób popełnienia przestępstwa,

8. zachowania popełniane bez przerwy czasowej, jak i w niewielkich odstępach czasowych,

9. jeden zamiar,

10.jeden plan,

11. ogólny cel,

12.ogólna motywacja.

37 „Продолжаемым признается преступление, слагаемое из неоднократных, объединенных единством вины и цели, тождественных деяний, представляющих отдельные акты единой деятельности лица, направленной на один и тот же непосредственный объект либо предмет посягательства для достижения общего результата" - М. СтАновский, op. cit.

38 „Единым продолжаемым преступлением призанется преступление, которое состоит из ряда отдельных тождественных действий, объединенных единым умыслом и направленных на один и тот же объект посягательства с целью достижения общего результата" - М.А. Фомин, Сбыт наркотитков: отграничение единого продолжаемого преступления от совокупности деяний [Zbyt narkotyków: odgraniczenie jednostkowego przestępstwa ciągłego od zbiegu czynów], «Уголовный процесс» 10/2012, s. 47.

39 Уголовное право России: Общзая часть: Учебник [Prawo karne Rosji: Czesść ogólna: Podręcznik], ред. Н.М. КропАчев, Б.В. ВолЖенкин, В.В. ОРеХОвА, СанктПетербург 2006, s. 617. 
Jednocześnie brak jednolitej pozycji doktryny co do tych kwestii określa się jako przyczynę, dla której niemożliwe jest wprowadzenie ustawowej definicji przestępstwa ciągłego ${ }^{40}$, co jednakże budzi zastrzeżenia z punktu widzenia zasady nullum crimen sine lege. Nie ulega jednak wątpliwości, że niezależnie od przyjmowanych przesłanek instytucja ta stanowi mechanizm redukcyjny, gdyż wielość czynów prowadzi do pociągnięcia do odpowiedzialności za jedno przestępstwo.

\section{PRZESTĘPSTWO CIĄGEE \\ WE WSPÓ£CZESNYM ROSYJSKIM PRAWIE KARNYM}

\section{Streszczenie}

Znamiennym dla współczesnego rosyjskiego prawa karnego jest fakt, że do tej pory postanowienie Plenum Sądu Najwyższego ZSRR z 4 marca 1929 r., które definiuje przestępstwo ciągłe, stanowi wstęp do rozważań o tej instytucji, co z polskiego punktu widzenia stanowi fenomen, gdyż żadnemu z judykatów wydanych w okresie PRL nie przypisywano tak ogromnego znaczenia. Należy także podkreślić, że również w obecnie obowiązującym rosyjskim Kodeksie karnym z 1996 r. nie uregulowano konstrukcji przestępstwa ciągłego, co tłumaczone jest tym, że po dzień dzisiejszy nie wypracowano wspólnego stanowiska odnośnie do jego przesłanek czy kształtu, co jednakże budzi zastrzeżenia z punktu widzenia zasady nullum crimen sine lege.

Continuous Crime in Contemporary Russian Criminal LaW

\section{Summary}

One of the striking features of contemporary Russian criminal law is the fact that the ruling of the Plenum of the Supreme Court of the USSR of 4th March 1929 defining 'continuous crime' is still the introduction to the deliberations on this institution, which from the Polish point of

40 Н.И. ПРяХИНА, В.Ф. ЩЕПЕЛЬКОВ, op. cit., 
view is remarkable, because none of the court decisions issued in Poland in the Communist period has been attributed such importance. It should also be noted that even though in the current Russian Penal Code (1996) there is no regulation for the construction of continuous crime, which is explained by the fact that a common position has still not been set forth on its premises or shape, which in turn raises concern from the point of view of the principle of nullum crimen sine lege.

Słowa kluczowe: przestępstwo ciągłe; zbieg przestępstw; rosyjskie prawo karne; prawo karne; mechanizm redukcyjny.

Keywords: continuous crime; concurrence of offences; Russian criminal law; criminal law; reduction mechanism.

\section{Literatura}

БАЙмаковА Н.Н., Длящиеся и продолжаемые преступления: время совершения и практическое значение момента их окончания [Przestępstwa ciagłe i trwałe: czas popetnienia i praktyczne znaczenia momentu ich zakończenia], «Российское правосудие» 3/2011

ВАсецов А., Квалификация повторных преступных посягательств на социалистическую и личную собственность [Kwalifikacja powtórnych przestępnych zamachów na socjalistyczną i prywatna własność], «Советская юстиция» $3 / 1983$

ВлАдимиРов В., Криволапов Г., Соотношение продолжаемых и повотрных nреступлений [Współzależność ciagłych i powtórnych przestępstw], «Советская юстиция» 19/1974

ВышинскАя 3.А., Судебная практика по делам о хищениях имущества в колхозах и совхозах, Научный комментарий по гражданским и уголовным делам [Orzecznictwo $w$ sprawach o zabór majątku w kołchozach $i$ sowchozach, [w:] Naukowy komentarz do orzecznictwa w sprawach cywilnych i karnych], Москва 1962

Иванов Н.Г., Уголовное право России. Общая и особенная части: Учебник для вузов [Prawo karne Rosji. Część ogólna i szczególna: Podręcznik dla uсzelni], Москва 2003

КАмынин И., Особенности определения сроков давности по длящимся и продолжаемым преступлениям [Osobliwości stosowania okresów przedawnienia do przestępstw trwałych i ciagtych], «Законность» 1/2004 
КаРаев Т.Э., Повторность преступлений [Powtórność przestępstw], Москва 1983

КвАшис В., Крутов Ю., Некоторые вопросы квалификации продолжаемых nреступлений [Niektóre zagadnienia kwalifikacji przestępstw ciagtych], «Советская юстиция» 12/1966

КливеР И., Разграничение продолжаемых и повторных преступлений [Odgraniczenie ciaglych i powtórnych przestępstw], «Советская юстиция» $5 / 1979$

А.П. КозЛов, А.П. Севастьянов., Единичные и множественные nреступления [Jednostkowe przestępstwa i wielość przestępstw], Санкт-Петербург 2011

КРемнев К., Миненок М., Квалификация продолжаемых и повторных хищений [Kwalifikacja ciąglych i powtórnych przestępstw], «Советская юстиция» 10/1990

КРОПАЧЕв Н.М., ВоЛЖЕНКИН Б.В., ОРеХОвА В.В. (ред.), Уголовное право Pоссии: Общая часть: Учебник [Prawo karne Rosji: Część ogólna: Podręcz$n i k]$, Санкт-Петербург 2006

Кузнецова Н.Ф., Квалибикация сложных составов преступлений [Kwalifikacja złożonych typów czynów zabronionych], «Уголовное право» 1/2000

Machlańska J., Przestępstwo ciagłe $w$ rosyjskim prawie karnym do 1929 r., «PiP» 70.9/2015

MACHLAŃsKa J., Wymiar kary za zbieg przestępstw i zbieg wyroków w rosyjskim prawie karnym, «CPKiNP» 3/2016

МАлков В.П., Повторность преступлений [Powtórność przestępstw], Казань 1970

Малков В.П., Совокупность преступлений [Zbieg przestępstw], Казань 1974

МУрашов Н.Ф., Преступление: вопросы и ответы ([по Уголовному кодексу Российской Федераици) [Przestępstwo: pytania i odpowiedzi (dot. Kodeksu karnego Federacji Rosyjskiej)], Москва 2001

ОрАздУРдыЕв А.М., Проблемы общей части науки уголовного права [Problemy nauki o ogólnej części prawa karnego], Ашхабад 1991

Пионтковский А.А., Уголовное право РСФСР. Общая часть [Prawo karne RFSSR. Część ogólna], Москва 1925

ПлоховА В.И., О продолжаемых хищениях, совершаемых в форме присвоения, растраты либо злоупотребления служебным положением, [w:] Эффективность уголовного права на современном этапе, отв. ред. М.И. КовАЛЕВ, [O ciagtych zaborach dokonanych $w$ formie przywłaszczenia, 
defraudacji albo nadużycia urzędowych obowiązków, [w:] Efektywność prawa karnego na współczesnym etapie], Свердлоск 1977

Пряхина Н.И., ЩЕПЕЛЬков В.Ф., Об отграничении продолжаемого преступления от совокупности преступлений [O rozgraniczeniu przestępstwa ciagłego od zbiegu przestępstw], «Криминалистъ»1/2011

СТАНовский М., Понятие продолжаемого преступления [Pojęcie przestępstwa ciagłego], «Российская юстиция» 11/1995

ТАГАНЦЕв Н.С., Русское уголовное право. Лекиии. Часть общая, II [Rosyjskie prawo karne. Wykłady. Część ogólna, II], Москва 1994

Фомин М.А., Сбыт наркотитков: отграничение единого продолжаемого преступления от совокупности деяний [Zbyt narkotyków: odgraniczenie jednostkowego przestępstwa ciagłego od zbiegu czynów], «Уголовный процесс» 10/2012

ЧучАев А.И., Постатейный комментарий к Уголовному кодексу Российской Федерации [Uzupetniony komentarz do kodeksu karnego Federacji Rosyjskiej], Москва 2004. 